\title{
Arganiella Giusti \& Pezzoli, 1980 (Caenogastropoda: Truncatelloidea: Hydrobiidae): a widespread genus or several narrow-range endemic genera?
}

\author{
Diana DELICADO ${ }^{1, *}$, Vladimir PEŠIĆ ${ }^{2} \&$ Marian A. RAMOS ${ }^{3}$ \\ ${ }^{1}$ Justus Liebig University Giessen, Department of Animal Ecology \& Systematics, \\ Heinrich-Buff-Ring 26-32 IFZD, 35392 Giessen, Germany. \\ ${ }^{2}$ University of Montenegro, Faculty of Sciences, Department of Biology, Cetinjski put b.b., \\ 81000 Podgorica, Montenegro. \\ ${ }^{3}$ Museo Nacional de Ciencias Naturales (MNCN-CSIC), José Gutiérrez Abascal 2, \\ 28006 Madrid, Spain. \\ *Corresponding author: didelicado@gmail.com \\ ${ }^{2}$ Email: vladopesic@gmail.com \\ ${ }^{3}$ Email: m.ramos@mncn.csic.es \\ ${ }^{1}$ urn:1sid:zoobank.org:author:ED8CD4C8-7310-40E3-8821-7721615A5992 \\ ${ }^{2}$ urn:1sid:zoobank.org:author:2B46F869-1202-47A9-9359-0BE04D691F6C \\ ${ }^{3}$ urn:1sid:zoobank.org:author:C108BACD-06A7-4C6D-8466-2A1CFE349DEB
}

\begin{abstract}
Most valvatiform genera of the gastropod family Hydrobiidae are narrow-range taxa. One exception is the genus Arganiella, which is comprised of three congeners: the type species $A$. pescei from the Apennine Peninsula, A. wolf from the Iberian Peninsula and A. tabanensis from the Balkans. The genus assignment of the latter two species was based on morphological similarities with $A$. pescei in the shell, operculum, radula and genitalia. Given that the morphology of hydrobiids is sometimes susceptible to convergence, this study re-evaluates the taxonomic status of species of Arganiella by analysing mitochondrial (mtCOI) and nuclear (18S rRNA) sequences of topotypes or near topotypes to infer their phylogenetic position. Our phylogenetic analyses depicted Arganiella as a non-monophyletic group within Hydrobiidae, and sequence divergence among the three species ranged from 14.5 to $16.7 \%$ for $\mathrm{mtCOI}$ and 2.0 to $3.8 \%$ for $18 \mathrm{~S}$. We also re-examined the extent of morphological variation among species of Arganiella and found a few differences among them and other valvatiform genera. Consequently, we propose two new genera for $A$. wolfi and A. tabanensis. Our results conflict with the classification of valvatiform hydrobiid species solely based on traditional phenotypical methods and suggest further taxonomic evaluation within a molecular framework.
\end{abstract}

Keywords. Springsnails, valvatiform hydrobiids, phylogeny, morphology, Mediterranean region.

Delicado D., Pešić V. \& Ramos M.A. 2021. Arganiella Giusti \& Pezzoli, 1980 (Caenogastropoda: Truncatelloidea: Hydrobiidae): a widespread genus or several narrow-range endemic genera? European Journal of Taxonomy 750 : 140-155. https://doi.org/10.5852/ejt.2021.750.1369 
DELICADO D. et al., Systematics of the hydrobiid genus Arganiella

\section{Introduction}

The gastropod genus Arganiella Giusti \& Pezzoli, 1980 (family Hydrobiidae Stimpson, 1865) comprises three narrow-range endemic species, each living on a different Mediterranean peninsula. These tiny springsnails $(1.0-1.5 \mathrm{~mm})$ have a depressed trochiform to valvatiform shell and simplified anatomical structures. The type species, A. pescei Giusti \& Pezzoli, 1980, was described from several wells and springs located in the central-eastern Apennine Peninsula (Giusti \& Pezzoli 1980). A proposed representative of the genus Boetersiella Arconada \& Ramos, 2001, B. wolfi Boeters \& Glöer, 2007, which is endemic to the southwestern Iberian Peninsula, was transferred to Arganiella by Arconada \& Ramos (2007a, 2007b). Based on morphological and geographical evidence, these authors also synonymized the species A. tartesica Arconada \& Ramos, 2007 with A. wolfi (Arconada \& Ramos 2007b). The third species, A. tabanensis Boeters, Glöer \& Pešić, 2014, was recently erected for a hydrobiid population living in a small rheocrene spring in Montenegro, in the Balkan Peninsula (Boeters et al. 2014).

The assignment of $A$. wolf $i$ and A. tabanensis to Arganiella was based on morphological similarity with the type species in shell, penis and female distal genital features (Arconada \& Ramos 2007a, 2007b; Boeters et al. 2014). However, such characters are susceptible to convergent evolution in valvatiform hydrobiid genera (Bodon et al. 2001) and, therefore, the systematics of the known species of Arganiella needs to be re-evaluated through molecular analyses. To date, DNA sequence data are available only for $A$. wolfi, and phylogenetic relationships inferred from a multilocus dataset of valvatiform hydrobiid genera from the Iberian Peninsula resolved $A$. wolfi as the sister taxon of the Iberian genus Iberhoratia Arconada \& Ramos, 2007 (Delicado et al. 2019). Sequence data from the other two species of Arganiella are needed to confidently assess the taxonomic composition of this wide-ranging genus.

As might be expected in taxa with poor dispersal capabilities, we hypothesize that phylogenetic analyses would depict species of Arganiella as three unrelated, narrow-range lineages rather than as a widely distributed monophyletic group. This result would challenge the genus assignment of these valvatiform hydrobiids, which was based on morphology, and limit the known geographic distribution of Arganiella to the Apennine Peninsula. To test these assumptions, we analyse new mitochondrial and nuclear DNA sequence data from the type species $A$. pescei and from $A$. tabanensis with previously published molecular datasets of valvatiform hydrobiids that also include sequences of $A$. wolfi (Delicado et al. 2019) in order to infer the phylogenetic relationships of the species of Arganiella and to quantify the degree of divergence among them. We also provide previously missing descriptions of the radular features of $A$. tabanensis for a morphological comparison. Finally, the taxonomic status of species of Arganiella is discussed in light of the evidence from the phylogenetic analyses and morphological comparisons of these taxa with other valvatiform hydrobiid genera recorded from the same Mediterranean regions.

\section{Material and methods}

We assessed the taxonomic status of the three recognized species of Arganiella using DNA sequence and morphological information from these and other valvatiform genera occurring in the Apennine, Balkan and Iberian peninsulas. One individual of $A$. pescei was used for the DNA assessment. This specimen was collected from Susanna Springs, in the region of the type locality (i.e., central-eastern Apennine Peninsula), and deposited in the collection of the University of Giessen Systematics and Biodiversity (UGSB) (Diehl et al. 2018) in Germany (UGSB 10365). Following an exhaustive morphological examination, Bodon et al. (2001) had assigned the hydrobiid populations living in these springs to $A$. pescei. Morphological characters from A. pescei were scored using the original description by Giusti \& Pezzoli (1980) and the re-description by Bodon et al. (2001). For the Iberian A. wolfi, we used the morphological description by Arconada \& Ramos (2007a) and Boeters \& Glöer (2007), and the sequences of a topotype used by Delicado et al. (2019) for the molecular analyses. The shell morphology and anatomy of the Balkan A. tabanensis are as illustrated by Boeters et al. (2014). Additional data on 
radular and opercular features of this species, as well as partial sequences of the studied DNA markers, were also collected for the present study. We collected ca 50 topotypes from the A. tabanensis type locality (Taban Spring, Montenegro; $42.52795^{\circ}$ N, 19.21921 ${ }^{\circ}$ E) in 2015 and preserved them in 80\% ethanol in the field. Shells and opercula were photographed using a Keyence VHX 2000 3D Digital Microscope. Six adults were dissected, and their buccal mass extracted, under an Olympus SZX12 stereo microscope. Radulae were extracted, cleaned and prepared as described by Delicado et al. (2016) for imaging on a field emission scanning electron microscope (FESEM) DSM982 Gemini (Carl Zeiss $\mathrm{GmbH}$, Germany). The collected specimens were then deposited in the UGSB collection (UGSB 18847).

We isolated total DNA from one individual per species (for $A$. pescei and A. tabanensis) following the CTAB protocol performed by Wilke et al. (2006). Fragments of the mitochondrial cytochrome $c$ oxidase subunit I (COI) and nuclear ribosomal 18S rRNA (18S) were amplified and sequenced using the primer pairs LCO1490 (Folmer et al. 1994) and COR722b (Davis et al. 1998) for COI and the universal primers for metazoan 18S (Holland et al. 1991). Amplification conditions for both gene fragments were as previously described by Delicado et al. (2012). The annealing temperature used was $52^{\circ} \mathrm{C}$. Samples were sequenced in an ABI 3730 XL sequencer (Life Technologies, Carlsbad, CA, USA) using a BigDye Terminator Kit ver. 3.1 (Life Technologies). The new sequences were deposited in GenBank (Table 1).

We assessed the taxonomy of the three species of Arganiella by analysing the COI and $18 \mathrm{~S}$ sequences of these species along with those of other European valvatiform and (closely related) non-valvatiform genera available from GenBank (Table 1). Forward and reverse sequences were aligned and edited in Sequencher ver. 5.4.6 (Gene Codes, Ann Arbor, MI). MEGA ver. 7.0.14 (Kumar et al. 2016) was used to assemble the gene-partition datasets and to calculate genetic distances (uncorrected $p$-distances). The COI dataset was manually aligned also using MEGA. The rRNA $18 \mathrm{~S}$ fragment was aligned using MAFFT ver. 7.402 (Katoh \& Standley 2013), with default settings for gap penalties. According to the corrected Akaike's information criterion (AICc; Akaike 1974; Sugiura 1978; Hurvich \& Tsai 1989), jModelTest ver. 2.1.7 (Darriba et al. 2012) selected TrN (Tamura \& Nei 1993) + I (invariable sites) + G (rate variation among sites) and TrNef (Tamura-Nei model with equal base frequencies; Tamura \& Nei 1993) + I + G models of nucleotide evolution for the COI and 18S datasets, respectively. We used DAMBE ver. 7 (Xia 2018) and the proportion of invariant sites (Pinv $=0.47)$ obtained in jModelTest to conduct the saturation test (Xia et al. 2003; Xia \& Lemey 2009) on the COI partition. The observed saturation $\left(\mathrm{I}_{\mathrm{ss}}=0.39\right)$ was significantly lower than the critical values $\left(\mathrm{I}_{\mathrm{ss.c}}=0.71 ; \mathrm{p}<0.001\right)$, suggesting little saturation in our COI dataset.

Phylogenetic analyses based on maximum likelihood (ML) methods were conducted using the RAxML BlackBox web-server [https://raxml-ng.vital-it.ch/\#/; Kozlov et al. 2019] with 10 random starting trees and the optimal substitution models for each gene partition selected in jModelTest. Bayesian inference (BI) analyses were run with mixed substitution models in MrBayes ver. 3.2.6 (Ronquist et al. 2012) for 5 million generations with a sampling frequency of 1000 . After verifying convergence of the BI analysis (standard deviation of split frequencies $<0.01$ ), the first $10 \%$ of generations were discarded as burn-in. Branch robustness was evaluated by rapid bootstrapping (BS) (Stamatakis et al. 2008) with an automatic cut-off for ML and by Bayesian posterior probability (BPP) for BI. Inferred topologies and branch supports were visualized in FigTree ver. 1.4.3 (Rambaut 2010).

For the morphological comparisons of species of Arganiella with other valvatiform hydrobiid genera from the Iberian, Apennine and Balkan peninsulas (Table 2), we scored morphological character states, including features of the shell, radula, operculum and anatomy, according to the information provided in the following studies: Arconada \& Ramos (2001) for Boetersiella and Chondrobasis Arconada \& Ramos, 2001; Girardi \& Boeters (2012) for Corbellaria Girardi \& Boeters, 2012; Delicado et al. (2019) for Deganta Arconada \& Ramos in Delicado et al., 2019; Arconada et al. (2007) for Iberhoratia Arconada \& Ramos, 2007; Arconada \& Ramos (2006) for Josefus Arconada \& Ramos, 
Table 1 (continued on next page). Taxon name, locality name, GenBank numbers and original references for sequences analysed in this study.

\begin{tabular}{|c|c|c|c|c|}
\hline Taxon & Locality & $\begin{array}{c}\text { GenBank \# } \\
18 S\end{array}$ & $\begin{array}{l}\text { GenBank \# } \\
\text { COI }\end{array}$ & Original reference \\
\hline Agrafia wiktori & $\begin{array}{l}\text { Agrafa Mountains, Sikiá, Evrytania, } \\
\text { Greece }(39.36861,21.63139)\end{array}$ & JF906758 & JF906765 & $\begin{array}{l}\text { Szarowska \& } \\
\text { Falniowski (2011) }\end{array}$ \\
\hline Alzoniella finalina & $\begin{array}{l}\text { Spring at the Porra River, Molino, } \\
\text { Liguria, Savona, Italy }(44.219,8.255)\end{array}$ & AF367686 & AF367650 & Wilke et al. (2001) \\
\hline Arganiella pescei & $\begin{array}{l}\text { Santa Susanna Springs, Rivodutri, } \\
\text { Latium, Italy }(42.49513,12.84604)\end{array}$ & MW561453 & MW553909 & Present study \\
\hline Arganiella tabanensis & $\begin{array}{l}\text { Taban Spring, Montenegro } \\
(42.52795,19.21921)\end{array}$ & MW561454 & MW553910 & Present study \\
\hline Arganiella wolfi & $\begin{array}{l}\text { Virgen de los Ángeles hermitage, } \\
\text { Sierra de Aracena, Huelva, Spain } \\
(37.8785,-6.66681)\end{array}$ & MH348095 & MH350192 & Delicado et al. (2019) \\
\hline Avenionia brevis & $\begin{array}{l}\text { Spring of the fountain of St.-Victor-La } \\
\text { Coste, Gard, France }(44.057,4.636)\end{array}$ & AF367670 & AF367638 & Wilke et al. (2001) \\
\hline Belgrandia thermalis & $\begin{array}{l}\text { Thermal channel near S. Giuliano, } \\
\text { Tuscany, Pisa, S. Giuliano Terme, } \\
\text { Italy }(43.751,10.440)\end{array}$ & AF367684 & AF367648 & Wilke et al. (2001) \\
\hline Belgrandiella kusceri & $\begin{array}{l}\text { Rakovski potok [Crab stream], near } \\
\text { Rakovski Skocjan, Rakek, Slovenia } \\
(45.77750,14.18556)\end{array}$ & JX970574 & KT218520 & $\begin{array}{l}\text { Wilke et al. (2013); } \\
\text { Falniowski \& Beran } \\
(2015)\end{array}$ \\
\hline Boetersiella sturmi & $\begin{array}{l}\text { La Mata Spring, Mata Bejid, Jaén, } \\
\text { Spain }(37.69503,-3.50703)\end{array}$ & MH348097 & MH350200 & Delicado et al. (2019) \\
\hline Bullaregia tunisiensis & $\begin{array}{l}\text { A spring in Djebba, Province Béja, } \\
\text { Tunisia }(36.47125,9.09972)\end{array}$ & MN575709 & KX821683 & $\begin{array}{l}\text { Khalloufi et al. (2017, } \\
\text { 2020) }\end{array}$ \\
\hline Chondrobasis levantina & $\begin{array}{l}\text { Caroche Spring, Teresa de Cofrentes, } \\
\text { Valencia, Spain }(39.09608,-0.91972)\end{array}$ & МH348098 & MH350203 & Delicado et al. (2019) \\
\hline Corbellaria celtiberica & $\begin{array}{l}\text { Manubles River, Soria, Spain } \\
(41.60997,-1.95586)\end{array}$ & МH348099 & MH350207 & Delicado et al. (2019) \\
\hline Daphniola graeca & $\begin{array}{l}\text { Daphne Spring, about } 30 \mathrm{~km} \text { north of } \\
\text { Larissa, Greece }(39.89111,22.60722)\end{array}$ & EF070624 & EU047764 & $\begin{array}{l}\text { Szarowska (2006); } \\
\text { Falniowski et al. } \\
(2007)\end{array}$ \\
\hline Deganta azarum & $\begin{array}{l}\text { La Fontona Spring, Borondes, } \\
\text { Asturias, Spain }(43.33189,-6.01494)\end{array}$ & МН348100 & MH350208 & Delicado et al. (2019) \\
\hline Fissuria boui & $\begin{array}{l}\text { Spring near La Prouveresse, Alpes } \\
\text { Maritimes, France ( } 43.64279 \text {, } \\
6.88735)\end{array}$ & AF367690 & AF367654 & Wilke et al. (2001) \\
\hline $\begin{array}{l}\text { Graecoarganiella } \\
\text { parnassiana }\end{array}$ & $\begin{array}{l}\text { Small spring south of Eptalofos, } \\
\text { Parnassus mountains, Greece } \\
(38.59278,22.5039)\end{array}$ & JN202341 & JN202348 & $\begin{array}{l}\text { Falniowski \& } \\
\text { Szarowska (2011a) }\end{array}$ \\
\hline Graziana alpestris & $\begin{array}{l}\text { Spring at the Porra River, Liguria, } \\
\text { Savona, Molino, Italy }(44.219,8.255)\end{array}$ & AF367673 & AF367641 & Wilke et al. (2001) \\
\hline Grossuana delphica & $\begin{array}{l}\text { Kastalia Spring at Delphi, Greece } \\
(38.48306,22.50528)\end{array}$ & EF061917 & EF061922 & Szarowska et al. (2007) \\
\hline Hauffenia tellinii & $\begin{array}{l}\text { Isonzo River near Sagrado Spring, } \\
\text { Friuli-Venetia Julia, Gorizia, Italy } \\
(45.8743,13.4856)\end{array}$ & AF367672 & AF367640 & Wilke et al. (2001) \\
\hline Horatia klecakiana & $\begin{array}{l}\text { Studenci Spring, N of Kučiće, in the } \\
\text { valley of the Cetina River, Croatia } \\
(43.44481,16.80708)\end{array}$ & KJ159127 & KJ159128 & $\begin{array}{l}\text { Szarowska \& } \\
\text { Falniowski (2014) }\end{array}$ \\
\hline Iberhoratia morenoi & $\begin{array}{l}\text { Prado del Rey Spring, Cádiz, Spain } \\
(36.66042,-5.45028)\end{array}$ & МH348101 & MH350210 & Delicado et al. (2019) \\
\hline
\end{tabular}


Table 1 (continued).

\begin{tabular}{|c|c|c|c|c|}
\hline Taxon & Locality & $\begin{array}{l}\text { GenBank \# } \\
\text { 18S }\end{array}$ & $\begin{array}{l}\text { GenBank \# } \\
\text { COI }\end{array}$ & Original reference \\
\hline Islamia piristoma & $\begin{array}{l}\text { Spring on right bank of Magra River } \\
\text { near Romito, Liguria, La Spezia, } \\
\text { Arcola, Italy }(44.1042,9.9337)\end{array}$ & AF367671 & AF367639 & Wilke et al. (2001) \\
\hline Josefus aitanica & $\begin{array}{l}\text { Flores Spring, Requena, Valencia, } \\
\text { Spain }(39.48694,-1.12205)\end{array}$ & MH348107 & MH350231 & Delicado et al. (2019) \\
\hline Kerkia kusceri & $\begin{array}{l}\text { Cave Krska jama, Krka, Ivancna } \\
\text { Gorica, Slovenia }(45.89,14.77111)\end{array}$ & KY087833 & KY087867 & Rysiewska et al. (2017) \\
\hline Mercuria similis & $\begin{array}{l}\text { La Puebla, Mallorca, Spain } \\
(39.79111,3.10472)\end{array}$ & AF212913 & AF213346 & Wilke et al. (2000) \\
\hline \multirow[t]{2}{*}{ Milesiana schuelei } & $\begin{array}{l}\text { Spring in Gaucin, Málaga, Spain } \\
(36.51878,-4.67703)\end{array}$ & - & MH350247 & Delicado et al. (2019) \\
\hline & $\begin{array}{l}\text { Spring in Berchul, Félix, Almería, } \\
\text { Spain }(36.87719,-2.66561)\end{array}$ & MH348108 & - & Delicado et al. (2019) \\
\hline Pauluccinella minima & Lago di Piediluco, S. Egidio, Italy & JX970578 & JX970612 & Wilke et al. (2013) \\
\hline \multirow[t]{2}{*}{ Sadleriana fluminensis } & $\begin{array}{l}\text { Jadro River at Solin near Split, } \\
\text { Croatia }(43.5453,16.48780)\end{array}$ & AF367683 & - & Wilke et al. (2001) \\
\hline & $\begin{array}{l}\text { Sava River, Slovenia } \\
(46.17344,14.41505)\end{array}$ & - & KF193083 & $\begin{array}{l}\text { Szarowska \& } \\
\text { Falniowski (2013) }\end{array}$ \\
\hline Spathogyna fezi & $\begin{array}{l}\text { Roble Spring, Yémeda, Cuenca, Spain } \\
(39.74281,-0.28383)\end{array}$ & MH348109 & MH350251 & Delicado et al. (2019) \\
\hline Tarraconia gasulli & $\begin{array}{l}\text { La Esperanza Spring, Navajas, } \\
\text { Castellón, Spain }(39.86990,-0.50719)\end{array}$ & MH348110 & MH350254 & Delicado et al. (2019) \\
\hline
\end{tabular}

2006 and Milesiana Arconada \& Ramos, 2006; Quiñonero-Salgado \& Rolán (2017) for shells of Navalis Quiñonero-Salgado \& Rolán, 2017; Boeters et al. (2019) for Salaeniella Boeters, Quiñonero-Salgado \& Ruiz-Cobo, 2019; Arconada \& Ramos (2002) for Spathogyna Arconada \& Ramos, 2002; Ramos et al. (2000) for Tarraconia Ramos \& Arconada, 2000; Falniowski \& Szarowska (2011a) for Graecoarganiella Falniowski \& Szarowska, 2011; Radea et al. (2013) for Isimerope Radea \& Parmakelis, 2013; Radea et al. (2016) for Myrtoessa Radea, 2016 and Bodon et al. (2001) for the remaining genera. Character and character states were coded following the terminology of Hershler \& Ponder (1998).

\section{Results}

\section{Molecular analyses}

The data matrix constructed of COI ( $658 \mathrm{bp}$ ) and $18 \mathrm{~S}$ (492 bp) sequences yielded an alignment with a total length of $1150 \mathrm{bp}$. Our ML and BI analyses generated similar tree topologies and branch supports (Fig. 1). In both inferences, Arganiella did not form a monophyletic group; instead, both $A$. wolf and A. tabanensis were distantly related to the type species $A$. pescei. Also in both analyses, $A$. wolf resolved as the sister taxon to the genus Iberhoratia from the Iberian Peninsula (BS $=100 \%, \mathrm{BPP}=1.00)$, and A.tabanensis, to the genus Kerkia Radoman, 1978 from the Balkan Peninsula and adjacent islands (BS =91\%, BPP = 0.95). The phylogenetic position of $A$. pescei was not well resolved in either of the phylogenetic analyses. Sequence divergence among the three species of Arganiella ranged from 14.5 to $16.7 \%$ for COI and 2.0 to $3.8 \%$ for $18 \mathrm{~S}$. Divergence among genera ranged from 9.1 to $22.5 \%$ for COI and 0 to $4.5 \%$ for $18 \mathrm{~S}$.

Overall, our results show that DNA sequence divergence values among the three species of Arganiella fall within the range of inter-generic variation and that both $A$. wolf $i$ and $A$. tabanensis not only have a sister group relationship with a genus from their respective Mediterranean peninsulas (Fig. 1) but also 
clear morphological differences with these sister genera, indicating the two species are representatives of distinct genera (Table 2). This evidence, altogether, demonstrates the need to revise the genus assignment of the non-type species $A$. wolfi and $A$. tabanensis.

\section{Taxonomy}

Phylum Mollusca Cuvier, 1795

Class Gastropoda Cuvier, 1795

Superorder Caenogastropoda Cox, 1960

Superfamily Truncatelloidea Gray, 1840

Family Hydrobiidae Stimpson, 1865

Genus Aretiana Delicado \& Ramos gen. nov.

urn:1sid:zoobank.org:act:7B207B6D-47E8-4211-8139-0CF98DA353D7

\section{Type species}

Boetersiella wolfi Boeters \& Glöer, 2007.

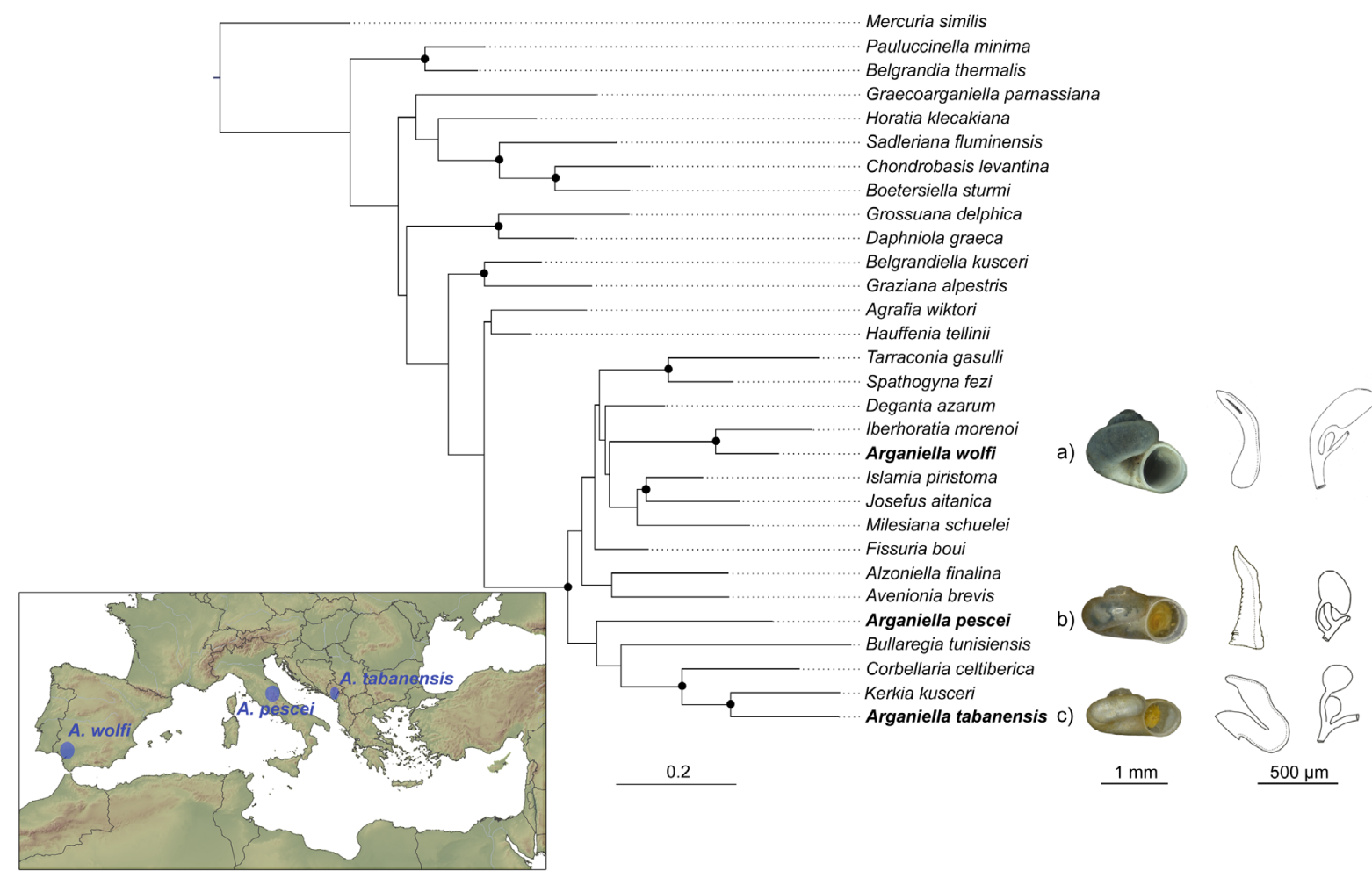

Fig. 1. Maximum likelihood tree based on the combined (COI, 18S) dataset. Statistical support of the nodes is indicated when Bayesian posterior probabilities $\geq 0.95$ and bootstrap supports $\geq 75 \%$ (black dots). On the right, the morphology of shell, penis and distal female genitalia is presented for: a) Arganiella wolfi Boeters \& Glöer, b) A. pescei Giusti \& Pezzoli, 1980 and c) A. tabanensis Boeters, Glöer \& Pešić, 2014. Reproductive organs were re-drawn from Arconada \& Ramos (2007a), Bodon et al. (2001) and Boeters et al. (2014) for the three species, respectively. Scale bar below topology: substitutions per site. 


\section{Revised diagnosis}

Shell trochiform; whorls 3.5-4.0; aperture complete, rounded; outer lip narrow, straight in lateral profile; umbilicus wide. Operculum corneous, yellowish, thin, pliable, oval to rounded, paucispiral with a central nucleus, without peg. Two pairs of basal cusps on each central radular tooth. Ctenidium well developed, with approximately 14 gill filaments. Osphradium positioned opposite to approximately the middle of the ctenidium. Stomach without gastric caecum; rectum forms a gentle U-shape in the mantle cavity. Bursa copulatrix medium-sized, pyriform, pedunculated and protruding beyond the posterior edge of the albumen gland; bursal duct shorter than bursal length; unpigmented renal oviduct that makes a complete loop over the pallial gland; one elongated or pyriform seminal receptacle arising from the renal oviduct, just above the insertion point with the bursal duct. Prostate gland bean-shaped, about twice as long as wide. Penis small and simple, gradually tapering. Nervous system unpigmented.

\section{Etymology}

The genus is named after Villa Aretiana, the Roman name of the town Aracena, which gives its name to the mountain range where the genus was found (i.e., Sierra de Aracena); gender feminine.

\section{Remarks}

Aretiana Delicado \& Ramos gen. nov. can be distinguished from Arganiella as the former has a taller shell, a more oval operculum, pigmentation on the body and eyespots, fewer gill filaments, a narrower penis, a larger and pyriform bursa copulatrix located beyond the posterior edge of the albumen gland and fewer cusps on the lateral radular teeth (for comparison, see Giusti \& Pezzoli 1980; Boeters \& Glöer 2007; Arconada \& Ramos 2007a). The new genus differs from the closely related genus Iberhoratia by its taller shell with a narrower umbilicus, the absence of lobes on the inner edge of the penis and of a proximal seminal receptacle (SR2) and presence of two pairs of basal cusps on each central radular tooth (see Arconada et al. 2007). Mean COI divergence for Aretiana Delicado \& Ramos gen. nov. was 15.9\% with Arganiella and $11.2 \%$ with Iberhoratia.

$$
\begin{aligned}
& \text { Genus Docleiana Delicado \& Pešić gen. nov. } \\
& \text { urn:1sid:zoobank.org:act:04639DB3-91D2-46B7-BFAB-FFC1EA3C27BD }
\end{aligned}
$$

\section{Type species}

Arganiella tabanensis Boeters, Glöer \& Pešić, 2014.

\section{Revised diagnosis}

Shell valvatiform; whorls ca 3; aperture complete, from rounded to ellipsoidal; outer lip narrow, straight in lateral profile; umbilicus wide. Operculum corneous, yellowish, thin, pliable, rounded, paucispiral with a central nucleus, without peg. Two pairs of basal cusps on each central radular tooth. Ctenidium well developed, with 10-11 gill filaments. Animal unpigmented. Osphradium positioned opposite approximately to the middle of the ctenidium. Stomach without gastric caecum; rectum forms a gentle V-shape in the mantle cavity. Bursa copulatrix small, globular, pedunculated and positioned beyond the posterior edge of the albumen gland; bursal duct longer than bursal length; unpigmented renal oviduct; one pyriform seminal receptacle arising at the insertion point with the bursal duct loop. Penis small and simple, gradually tapering.

\section{Etymology}

The new genus is named after Doclea, the name of the Roman city located on the site of modern Podgorica on whose municipal territory a new genus was found; gender feminine. 


\section{Remarks}

Docleiana Delicado \& Pešić gen. nov. can be distinguished from Arganiella as the former has a more ellipsoidal shell aperture, a narrower base of the penis, a smaller bursa copulatrix that is positioned beyond the posterior edge of the albumen gland, a larger seminal receptacle and more cusps on the lateral radular teeth (Fig. 2; for comparison, see Giusti \& Pezzoli 1980; Boeters et al. 2014). The new genus differs from the closely related genus Kerkia by its smaller shell, absence of lobes on the inner edge of the penis, a smaller bursa copulatrix, a more globular seminal receptacle and V-shaped rectum (see Radoman 1978; Bodon et al. 2001). Mean COI sequence divergence for Docleiana Delicado \& Pešić gen. nov. was $14.5 \%$ with Arganiella and $12.3 \%$ with Kerkia.

\section{Discussion}

Previous taxonomic studies of valvatiform hydrobiids have relied on morphological similarities to classify species, a practice that can be difficult for this group because of their small size and simplified morphologies. Considering this, more recent systematic revisions have incorporated molecular

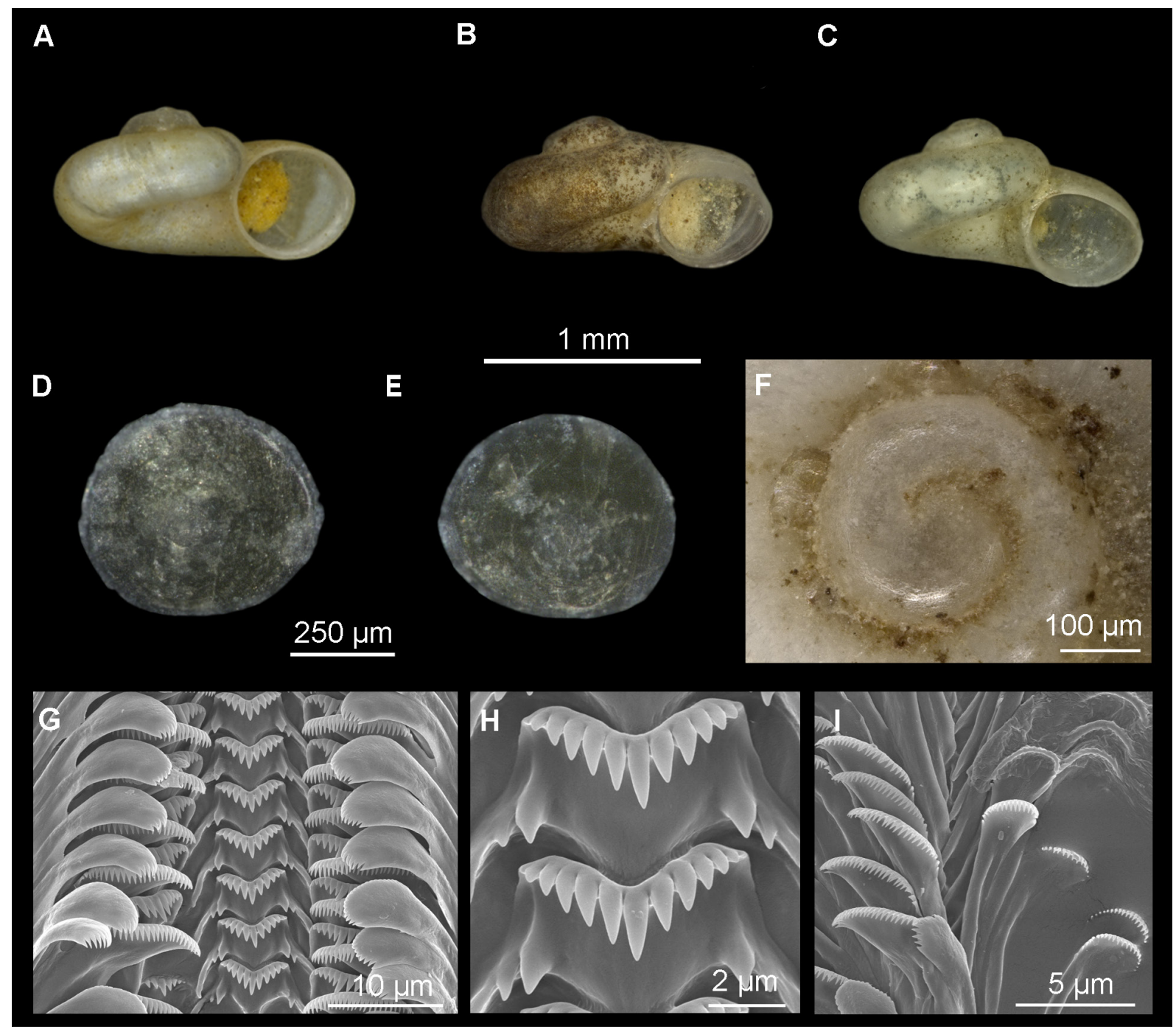

Fig. 2. Shells, operculum and radulae of Docleiana tabanensis (Boeters, Glöer \& Pešić, 2014) (UGSB 18847). A-C. Shells. D-E. Operculum (D = inner side; $E=$ outer side). F. Protoconch. G-I. Radulae. G. Portion of radula ribbon. H. Central radular teeth. I. Inner and outer marginal teeth. 
methods to re-evaluate the taxonomy of valvatiform hydrobiid species and have indeed revealed genus misidentifications. Some examples are the species Hauffenia plana (Bole, 1961), later transferred to the genus Bracenica Radoman, 1973 by Hofman et al. (2020); Horatia hadei Gittenberger, 1982 transferred to Daphniola Radoman, 1973 by Falniowski \& Szarowska (2011b); and Neohoratia azarum Boeters \& Rolán, 1988, later recognized as Islamia azarum (Boeters \& Rolán, 1988) by Arconada \& Ramos (2006) and currently combined as Deganta azarum by Arconada \& Ramos in Delicado et al. (2019). In the case of Arganiella, A. wolfi and A. tabanensis, two endemic species from the Iberian and Balkan peninsulas, respectively, were classified within this genus on the basis of shell and genital similarities with the Apennine species A. pescei (Arconada \& Ramos 2007a, 2007b; Boeters et al. 2014). Our survey of DNA sequence divergence within Arganiella, although based on a limited number of samples and gene fragments, showed the substantial divergence of these two species from the type species A. pescei ( $>14.5 \%$ for COI). This degree of DNA sequence differentiation is comparable to those inferred between other recognized valvatiform genera (uncorrected $p$-distances $9.1-22.5 \%$ for COI). Moreover, Arganiella was not recovered as a monophyletic group by our phylogenetic inferences (Fig. 1).

However, incorrect systematic conclusions can be drawn from molecular phylogenies when the specimens have previously been misidentified (e.g., Radomaniola/Horatia in Szarowska \& Falniowski, 2014). Detailed morphological examinations of the studied material are therefore needed for a more reliable systematic interpretation. Our comparative morphological study (Table 2) indicated close similarities among the, until now, considered species of Arganiella, especially in those characters related to the penis, ctenidium and radula and, to a lesser degree, the shell, pigmentation and distal genitalia of females. Some character states found in species of Arganiella, such as a simple penis without lobes, the presence of a single distal seminal receptacle and two cusps at both sides of the basis of the central radular tooth, are rarely present in other valvatiform genera (Bodon et al. 2001; Radea et al. 2016) and can, thus, lead to genus misidentification. However, differences in other characters can be observed among the three species. The most dissimilar species is $A$. wolfi: it has a larger and more trochiform shell, body pigmentation and a larger bursa copulatrix (Arconada \& Ramos 2007a; Boeters \& Glöer 2007). Arganiella tabanensis is more similar to A. pescei than $A$. wolf, especially in shell shape and body pigmentation (Boeters et al. 2014). However, it differs from A. pescei in shell size, the shape of the bursa copulatrix and the bend type of the rectum. On the basis of this DNA and morphologic evidence, we assign the species $A$. wolf $i$ and $A$. tabanensis to two distinct genera.

We base the establishment of the two new genera, Aretiana Delicado \& Ramos gen. nov. for Arganiella wolfi and Docleiana Delicado \& Pešić gen. nov. for Arganiella tabanensis, on the high level of DNA sequence divergence and phylogenetic position of the two species (Fig. 1), as well as on their unique combination of morphological characters (Table 2). Given the restricted geographic distribution of most valvatiform hydrobiids (Bodon et al. 2001), we focus our taxonomic decision on comparisons with geographically close groups. Most genera of Iberian valvatiform hydrobiids were included in our phylogenetic study, except Navalis, which is only known by empty shells, and Salaeniella, for which the females are still unknown and no well-preserved specimens are available for molecular studies. Regardless, these genera are morphologically very distinct from Aretiana Delicado \& Ramos gen. nov. and have distant distribution ranges within the Iberian Peninsula (Quiñonero-Salgado \& Rolán 2017; Boeters et al. 2019). According to our comparative morphological study, the most similar Iberian genus to Aretiana Delicado \& Ramos gen. nov. is Boetersiella. These two genera are highly divergent genetically and display clear differences in shell and female genital features, validating them as different genera. DNA sequence data of valvatiform genera living in the Balkan springs are still scarce. Although our phylogenetic analyses recovered Docleiana Delicado \& Pešić gen. nov. as an independent lineage sister to the Balkan genus Kerkia, this relationship may change as more valvatiform species are sequenced and analysed. Until then, morphological characters support the placement of A. tabanensis into a new genus. The Balkan genera Hadziella Kuščer, 1932 and Dabriana Radoman, 1974, which have not yet 


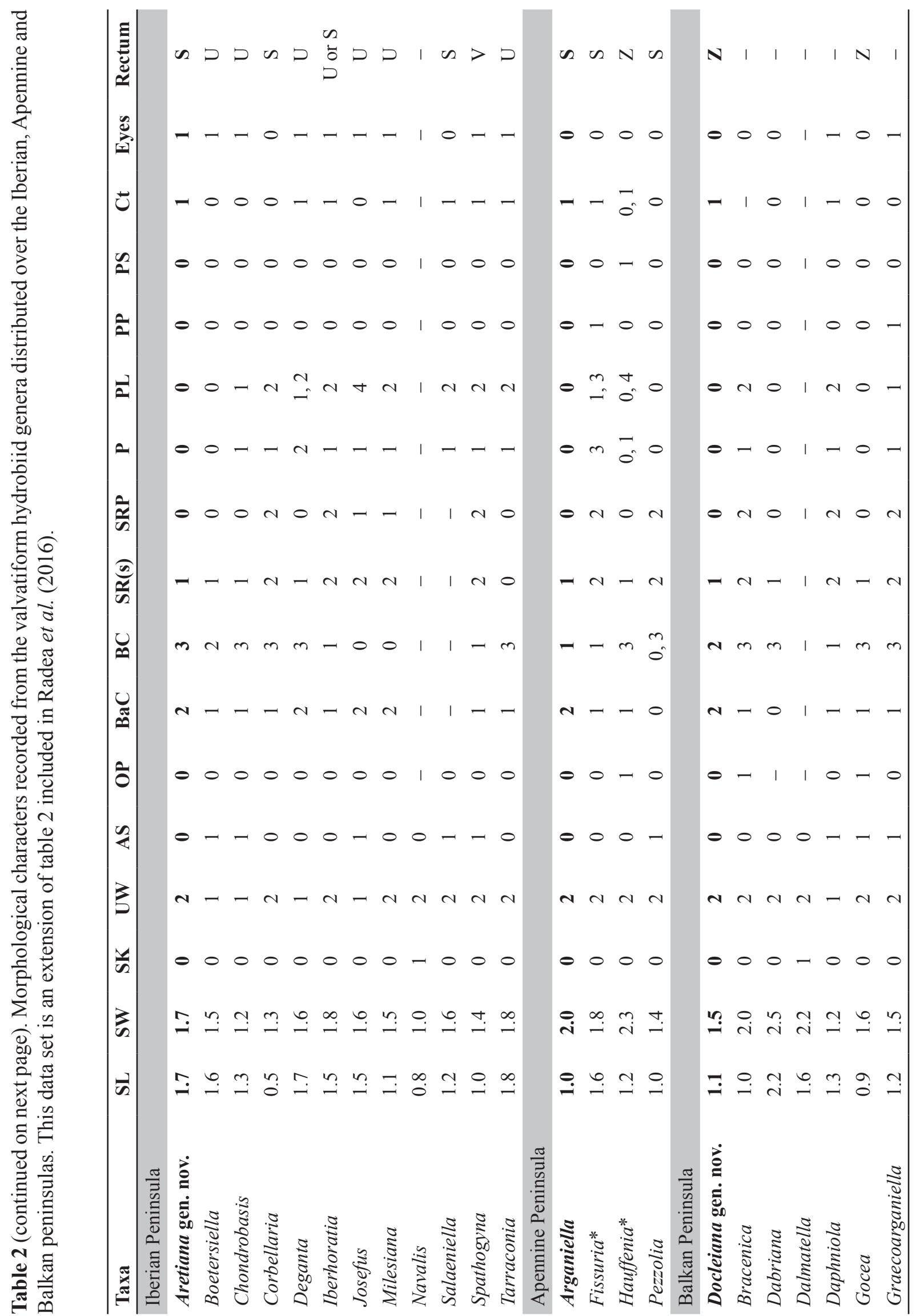




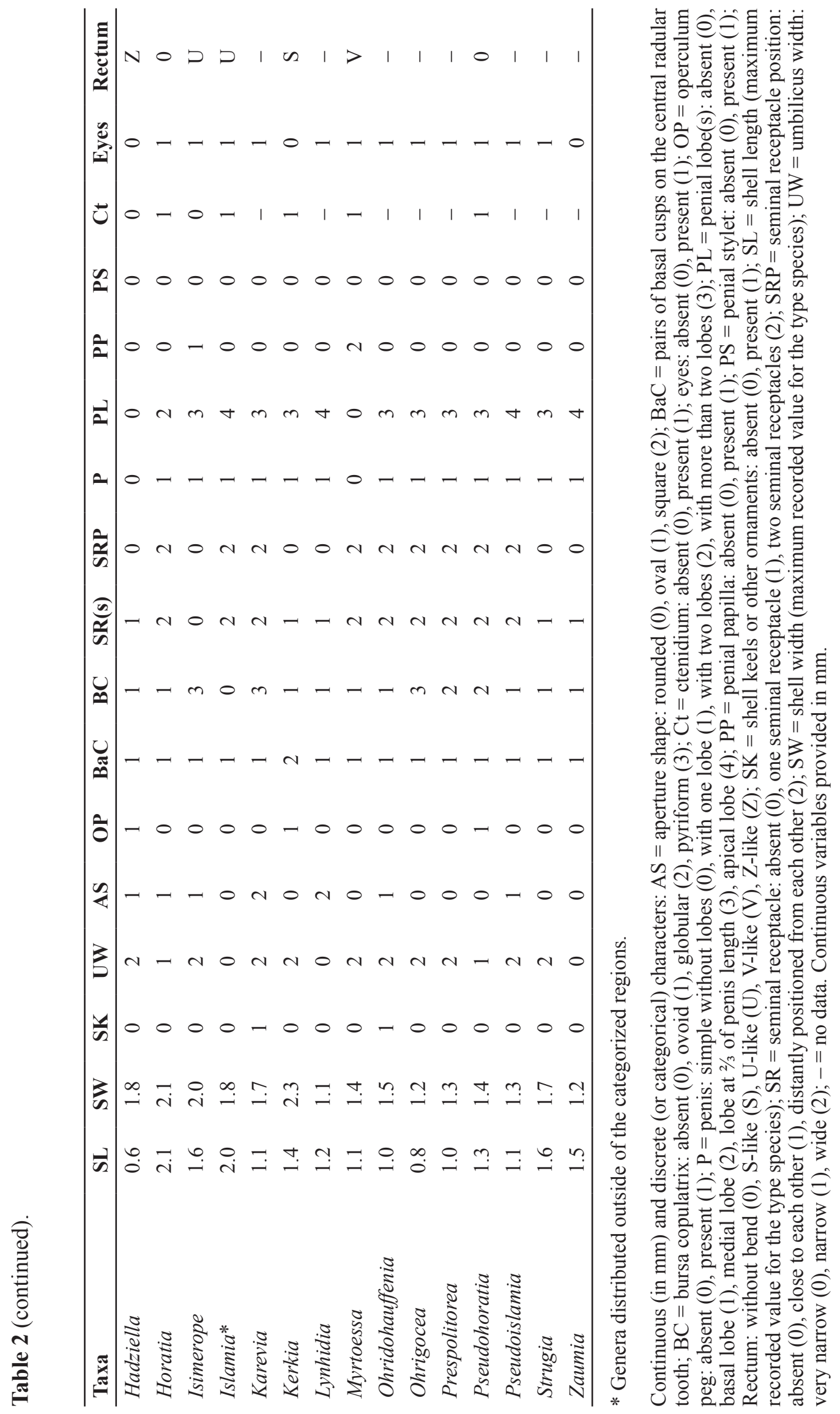


DELICADO D. et al., Systematics of the hydrobiid genus Arganiella

been sequenced, resemble Docleiana Delicado \& Pešić gen. nov. in penis morphology but differ in shell size and radular and female genital features; they also lack a ctenidium (Table 2).

The systematic findings suggesting erroneous assignment of the three geographically disjunct species to the same genus due to morphological similarities conflict with the use of traditional taxonomy to classify valvatiform hydrobiid taxa and highlight the need to integrate morphological and molecular data for more robust taxonomic assessments.

\section{Acknowledgements}

We thank S. Cianfanelli for collecting and depositing a sample of A. pescei in the UGSB collection at Justus Liebig University, Giessen, and A. Möbus and S. Agel (Imaging Unit, Biomedical Research Centre Seltersberg, Justus Liebig University, Giessen) for their assistance with the ESEM photomicrographs. We are also grateful to M. Haase, another anonymous reviewer and the Section editor T. Backeljau for their helpful comments on earlier versions of the manuscript. The English was reviewed by M. Modrell. This work was funded by a German Science Foundation (DFG) grant (DE 2605/1-1) to D. Delicado and the Fauna Iberica XII project (PGC2018-095851-B-C61) to M.A. Ramos.

\section{References}

Akaike H. 1974. A new look at the statistical model identification. IEEE Transactions on Automatic Control 19 (6): 716-723. https://doi.org/10.1109/TAC.1974.1100705

Arconada B. \& Ramos M.A. 2001. New data on Hydrobiidae systematics: two new genera from the Iberian Peninsula. Journal of Natural History 35: 949-984. https://doi.org/10.1080/002229301300323884

Arconada B. \& Ramos M.A. 2002. Spathogyna, a new genus for Valvata (? Tropidina) fezi Altimira, 1960 from eastern Spain: another case of pseudohermaphroditism in the Hydrobiidae (Gastropoda). Journal of Molluscan Studies 68 (4): 319-327. https://doi.org/10.1093/mollus/68.4.319

Arconada B. \& Ramos M.A. 2006. Revision of the genus Islamia Radoman, 1973 (Gastropoda, Caenogastropoda, Hydrobiidae), on the Iberian Peninsula and description of two new genera and three new species. Malacologia 48 (1-2): 77-132.

Arconada B. \& Ramos M.A. 2007a. Description of a new species of the genus Arganiella Giusti \& Pezzoli, 1980 (Mollusca, Gastropoda, Hydrobiidae) from the Iberian Peninsula. Graellsia 63 (1): 61-70. https://doi.org/10.3989/graellsia.2007.v63.i1.81

Arconada B. \& Ramos M.A. 2007b. Arganiella wolfi, new combination for Boetersiella wolfi (Boeters \& Glöer, 2007). Graellsia 63 (2): 367-369. https://doi.org/10.3989/graellsia.2007.v63.i2.105

Arconada B., Delicado D. \& Ramos M.A. 2007. A new genus and two new species of Hydrobiidae (Mollusca, Caenogastropoda) from the Iberian Peninsula. Journal of Natural History 41 (29-32): 20072035. https://doi.org/10.1080/00222930701529273

Bodon M., Manganelli G. \& Giusti F. 2001. A survey of the European valvatiform hydrobiid genera with special reference to Hauffenia Pollonera, 1898 (Gastropoda: Hydrobiidae). Malacologia 43: 103-215.

Boeters H.D. \& Glöer P. 2007. A contribution to the genus Boetersiella Arconada \& Ramos 2001 in Spain with the description of Boetersiella wolf $\mathrm{n}$. sp. Heldia 5: 85-88.

Boeters H.D., Glöer P. \& Pešić V. 2014. Arganiella tabanensis n. sp. from Montenegro (Mollusca: Gastropoda: Hydrobiidae). Ecologica Montenegrina 1 (3): 131-139.

https://doi.org/10.37828/em.2014.1.20 
Boeters H.D., Quiñonero-Salgado S. \& Ruiz-Cobo J. 2019. A new genus for a new valvatiform hydrobiid from northwestern Spain (Gastropoda: Caenogastropoda: Hydrobiidae). Folia Malacologica 27 (2): 101-105. https://doi.org/10.12657/folmal.027.009

Darriba D., Taboada G.L., Doallo R. \& Posada D. 2012. jModelTest 2: more models, new heuristics and parallel computing. Nature Methods 9 (8): 772-772. https://doi.org/10.1038/nmeth.2109

Davis G.M., Wilke T., Spolsky C., Qiu C.-P., Qiu D.-C., Xia M.-Y., Zhang Y. \& Rosenberg G. 1998. Cytochrome oxidase I-based phylogenetic relationships among the Pomatiopsidae, Hydrobiidae, Rissoidae and Truncatellidae (Gastropoda: Caenogastropoda: Rissoacea). Malacologia 40: 251-266.

Delicado D., Machordom A. \& Ramos M.A. 2012. Underestimated diversity of hydrobiid snails. The case of Pseudamnicola (Corrosella) (Mollusca: Caenogastropoda: Hydrobiidae). Journal of Natural History 46 (1-2): 25-89. https://doi.org/10.1080/00222933.2011.623358

Delicado D., Pešić V. \& Glöer P. 2016. Unraveling a new lineage of Hydrobiidae genera (Caenogastropoda: Truncatelloidea) from the Ponto-Caspian region. European Journal of Taxonomy 208: 1-29. https://doi.org/10.5852/ejt.2016.208

Delicado D., Arconada B., Aguado A. \& Ramos M.A. 2019. Multilocus phylogeny, species delimitation and biogeography of Iberian valvatiform springsnails (Caenogastropoda: Hydrobiidae), with the description of a new genus. Zoological Journal of the Linnean Society 186 (4): 892-914.

https://doi.org/10.1093/zoolinnean/zly093

Diehl E., Jauker B., Albrecht C., Wilke T. \& Wolters V. 2018. GIEßEN: University Collections: Justus Liebig University Gießen. In: Zoological Collections of Germany: 373-381. Springer, Cham. https://doi.org/10.1007/978-3-319-44321-8_29

Falniowski A. \& Beran L. 2015. Belgrandiella A. J. Wagner, 1928 (Caenogastropoda: Truncatelloidea: Hydrobiidae): how many endemics? Folia Malacologica 23 (3): 187-191.

https://doi.org/10.12657/folmal.023.015

Falniowski A. \& Szarowska M. 2011a. A new genus and new species of valvatiform hydrobiid (Rissooidea; Caenogastropoda) from Greece. Molluscan Research 31 (3): 189-199.

Falniowski A. \& Szarowska M. 2011b. The genus Daphniola Radoman, 1973 (Caenogastropoda: Hydrobiidae) in the Peloponnese, Greece. Folia Malacologica 19 (3): 131-137.

https://doi.org/10.2478/v10125-011-0020-9

Falniowski A., Szarowska M. \& Grzmil P. 2007. Daphniola Radoman, 1973 (Gastropoda: Hydrobiidae): shell biometry, mtDNA, and the Pliocene flooding. Journal of Natural History 41 (37-40): 2301-2311. https://doi.org/10.1080/00222930701630733

Folmer O., Black M., Hoeh W., Lutz R. \& Vrijenhoek R. 1994. DNA primers for amplification of mitochondrial cytochrome $c$ oxidase subunit I from diverse metazoan invertebrates. Molecular Marine Biology and Biotechnology 3 (5): 294-299.

Girardi H. \& Boeters H.D. 2012. Corbellaria celtiberica gen. et sp. nov. (Gastropoda: Hydrobiidae), mollusque valvatiforme stygobie de la province de Soria (Péninsule Ibérique). Spira 4 (3-4): 149-160.

Giusti F. \& Pezzoli E. 1980. Hydrobioidea nuove o poco conosciute dell Italia appenninica (Gastropoda: Prosobranchia). Archiv für Molluskenkunde 111: 207-222.

Hershler R. \& Ponder W.F. 1998. A review of the morphological characters of hydrobioid snails. Smithsonian Contributions to Zoology 600: 1-55. https://doi.org/10.5479/si.00810282.600

Hofman S., Grego J., Rysiewska A., Osikowski A., Falniowski A., Erőss Z.P. \& Fehér Z. 2020. Phylogenetic relationships of Bracenica Radoman, 1973 (Caenogastropoda: Truncatelloidea). Folia Malacologica 28 (2): 121-131. https://doi.org/10.12657/folmal.028.009 
Holland P.W.H., Hacker A.M. \& Williams N.A. 1991. A molecular analysis of the phylogenetic affinities of Saccoglossus cambrensis Brambell \& Cole (Hemichordata). Philosophical Transactions of the Royal Society B: Biological Sciences 332 (1264): 185-189. https://doi.org/10.1098/rstb.1991.0048

Hurvich C.M. \& Tsai C.-L. 1989. Regression and time series model selection in small samples. Biometrika 76 (2): 297-307. https://doi.org/10.1093/biomet/76.2.297

Katoh K. \& Standley D.M. 2013. MAFFT multiple sequence alignment software version 7: improvements in performance and usability. Molecular Biology and Evolution 30 (4): 772-780.

https://doi.org/10.1093/molbev/mst010

Khalloufi N., Béjaoui M. \& Delicado D. 2017. A new genus and species of uncertain phylogenetic position within the family Hydrobiidae (Caenogastropoda: Truncatelloidea) discovered in Tunisian springs. European Journal of Taxonomy 328: 1-15. https://doi.org/10.5852/ejt.2017.328

Khalloufi N., Béjaoui M. \& Delicado D. 2020. Two new genera and three new subterranean species of Hydrobiidae (Caenogastropoda: Truncatelloidea) from Tunisia. European Journal of Taxonomy 648: 1-27. https://doi.org/10.5852/ejt.2020.648

Kozlov A.M., Darriba D., Flouri T., Morel B. \& Stamatakis A. 2019. RAxML-NG: a fast, scalable and user-friendly tool for maximum likelihood phylogenetic inference. Bioinformatics 35 (21): 4453-4455. https://doi.org/10.1093/bioinformatics/btz305

Kumar S., Stecher G. \& Tamura K. 2016. MEGA7: Molecular Evolutionary Genetics Analysis version 7.0 for bigger datasets. Molecular Biology and Evolution 33 (7): 1870-1874.

https://doi.org/10.1093/molbev/msw054

Quiñonero-Salgado S. \& Rolán E. 2017. Navalis perforatus a new genus and new species (Gastropoda, Hydrobiidae) from Spain. Nemus 7: 7-11.

Radea C., Parmakelis A., Mourikis T. \& Triantis K.A. 2013. Isimerope, a new genus of Hydrobiidae (Caenogastropoda: Rissooidea) from Greece. Journal of Molluscan Studies 79 (2): 168-176.

https://doi.org/10.1093/mollus/eyt010

Radea C., Parmakelis A. \& Giokas S. 2016. Myrtoessa hyas, a new valvatiform genus and a new species of the Hydrobiidae (Caenogastropoda, Truncatelloidea) from Greece. ZooKeys 640: 1-18.

https://doi.org/10.3897/zookeys.640.10674

Radoman P. 1978. Neue Vertreter der Gruppe Hydrobioidea von der Balkanhalbinsel. Archiv für Molluskenkunde 109 (1-3): 27-44.

Rambaut A. 2010. FigTree. Available from http://ree.bio.ed.ac.uk/software/figtree [accessed 30 Apr. 2021].

Ramos M.A., Arconada B., Moreno D. \& Rolán E. 2000. A new genus and a new species of Hydrobiid snail (Mollusca: Gastropoda: Hydrobiidae) from eastern Spain. Malacologia 42 (1-2): 75-101.

Ronquist F., Teslenko M., Van Der Mark P., Ayres D.L., Darling A., Höhna S., Larget B., Liu L., Suchard M.A. \& Huelsenbeck J.P. 2012. MrBayes 3.2: efficient Bayesian phylogenetic inference and model choice across a large model space. Systematic Biology 61 (3): 539-542.

https://doi.org/10.1093/sysbio/sys029

Rysiewska A., Prevorčnik S., Osikowski A., Hofman S., Beran L. \& Falniowski A. 2017. Phylogenetic relationships in Kerkia and introgression between Hauffenia and Kerkia (Caenogastropoda: Hydrobiidae). Journal of Zoological Systematics and Evolutionary Research 55 (2): 106-117.

https://doi.org/10.1111/jzs.12159 
Stamatakis A., Hoover P. \& Rougemont J. 2008. A rapid bootstrap algorithm for the RAxML web servers. Systematic Biology 57 (5): 758-771. https://doi.org/10.1080/10635150802429642

Sugiura N. 1978. Further analysts of the data by Akaike's information criterion and the finite corrections. Communications in Statistics - Theory and Methods 7 (1): 13-26.

https://doi.org/10.1080/03610927808827599

Szarowska M. 2006. Molecular phylogeny, systematics and morphological character evolution in the Balkan Rissooidea (Caenogastropoda). Folia Malacologica 14: 99-168.

https://doi.org/10.12657/folmal.014.014

Szarowska M. \& Falniowski A. 2011. An unusual, flagellum-bearing hydrobiid snail (Gastropoda: Rissooidea: Hydrobiidae) from Greece, with descriptions of a new genus and a new species. Journal of Natural History 45 (35-36): 2231-2246. https://doi.org/10.1080/00222933.2011.591067

Szarowska M. \& Falniowski A. 2013. Species distinctness of Sadleriana robici (Clessin, 1890) (Gastropoda: Rissooidea). Folia Malacologica 21 (3): 127-133. https://doi.org/10.12657/folmal.021.016

Szarowska M. \& Falniowski A. 2014. Horatia Bourguignat, 1887: is this genus really phylogenetically very close to Radomaniola Szarowska, 2006 (Caenogastropoda: Truncatelloidea)? Folia Malacologica 22 (1): 31-39. https://doi.org/10.12657/folmal.022.003

Szarowska M., Grzmil P., Falniowski A. \& Sirbu I.O. 2007. Grossuana codreanui (Grossu, 1946) and the phylogenetic relationships of the East Balkan genus Grossuana (Radoman, 1973) (Gastropoda: Rissooidea). Hydrobiologia 579: 379-391. https://doi.org/10.1007/s10750-006-0530-4

Tamura K. \& Nei M. 1993. Estimation of the number of nucleotide substitutions in the control region of mitochondrial DNA in humans and chimpanzees. Molecular Biology and Evolution 10 (3): 512-526.

Wilke T., Davis G.M., Gong X. \& Liu H.X. 2000. Erhaia (Gastropoda: Rissooidea): phylogenetic relationships and the question of Paragonimus coevolution in Asia. The American Journal of Tropical Medicine and Hygiene 62 (4): 453-459. https://doi.org/10.4269/ajtmh.2000.62.453

Wilke T., Davis G.M., Falniowski A., Giusti F., Bodon M. \& Szarowska M. 2001. Molecular systematics of Hydrobiidae (Mollusca: Gastropoda: Rissooidea): testing monophyly and phylogenetic relationships. Proceedings of the Academy of Natural Sciences of Philadelphia 151 (1): 1-21. https://doi.org/10.1635/0097-3157(2001)151[0001:MSOHMG]2.0.CO;2

Wilke T., Davis G.M., Qiu D.C. \& Spear R.C. 2006. Extreme mitochondrial sequence diversity in the intermediate schistosomiasis host Oncomelania hupensis robertsoni: another case of ancestral polymorphism? Malacologia 48 (1-2): 143-157.

Wilke T., Haase M., Hershler R., Liu H.-P., Misof B. \& Ponder W. 2013. Pushing short DNA fragments to the limit: phylogenetic relationships of 'hydrobioid' gastropods (Caenogastropoda: Rissooidea). Molecular Phylogenetics and Evolution 66 (3): 715-736. https://doi.org/10.1016/j.ympev.2012.10.025

Xia X. 2018. DAMBE7: new and improved tools for data analysis in molecular biology and evolution. Molecular Biology and Evolution 35 (6): 1550-1552. https://doi.org/10.1093/molbev/msy073

Xia X. \& Lemey P. 2009. Assessing substitution saturation with DAMBE. In: The Phylogenetic Handbook. Second edition. Cambridge University Press.

Xia X., Xie Z., Salemi M., Chen L. \& Wang Y. 2003. An index of substitution saturation and its application. Molecular Phylogenetics and Evolution 26 (1): 1-7. https://doi.org/10.1016/S1055-7903(02)00326-3

Manuscript received: 17 December 2020

Manuscript accepted: 3 March 2021 
Published on: 21 May 2021

Topic editor: Rudy Jocqué

Section editor: Thierry Backeljau

Desk editor: Pepe Fernández

Printed versions of all papers are also deposited in the libraries of the institutes that are members of the EJT consortium: Muséum national d'histoire naturelle, Paris, France; Meise Botanic Garden, Belgium; Royal Museum for Central Africa, Tervuren, Belgium; Royal Belgian Institute of Natural Sciences, Brussels, Belgium; Natural History Museum of Denmark, Copenhagen, Denmark; Naturalis Biodiversity Center, Leiden, the Netherlands; Museo Nacional de Ciencias Naturales-CSIC, Madrid, Spain; Real Jardín Botánico de Madrid CSIC, Spain; Zoological Research Museum Alexander Koenig, Bonn, Germany; National Museum, Prague, Czech Republic. 